\title{
Repassivation Behaviour of UNS S32101 and UNS S30403 Stainless Steels after Cathodic Stripping of the Native Passive Film in a $\mathrm{CO}_{2}$-Saturated Oilfield Brine
}

\author{
Sunday Aribo \\ Department of Metallurgical and Materials Engineering, Federal University of Technology, Akure, \\ Nigeria \\ Email: aribosunny@yahoo.com, saribo@futa.edu.ng
}

Received 1 June 2015; accepted 2 August 2015; published 5 August 2015

Copyright (C) 2015 by author and Scientific Research Publishing Inc.

This work is licensed under the Creative Commons Attribution International License (CC BY). http://creativecommons.org/licenses/by/4.0/

(c) (i) Dpen Access

\begin{abstract}
Repassivation behaviour of the passive film formed on lean duplex stainless steel UNS S32101 and austenitic stainless steel UNS $\mathbf{S 3 0 4 0 3}$ in a $\mathrm{CO}_{2}$-saturated oilfield environment has been studied. The native passive film on the alloys was thinned/removed by stepping the potential of the alloy to $-\mathbf{8 5 0} \mathrm{mV} / \mathrm{Ag} / \mathrm{AgCl}$ for 30 minutes. Potentiostatic measurements were then taken at potentials of $-200,-100,0,100$ and $200 \mathrm{mV}$ versus $\mathrm{Ag} / \mathrm{AgCl}$. Results show that the passive film repassivates at potentials of -200 and $-100 \mathrm{mV}$ and $0 \mathrm{mV}$ for both alloys at $50^{\circ} \mathrm{C}$. The current density however continues to rise for potentials of 100 and $200 \mathrm{mV}$. This shows that both alloys are susceptible to pitting at potentials above $100 \mathrm{mV}$ at the test temperature of $50^{\circ} \mathrm{C}$.
\end{abstract}

Keywords

UNS S32101, UNS S30403, Cathodic Stripping, Repassivation, Passive Film

\section{Introduction}

The behavior of stainless steels in aqueous solution has been widely studied. It is widely agreed that the alloying elements help in the formation of the protective passive film [1] [2]. This film is stable, invisible, thin durable and extremely adherent and self-repairing. The stability of the film depends on the nature of the corroding metal and ions present in the solution [3]. In order to prevent corrosion, it is important that stainless steels have stable passive film with rapid passivation in severe environments [4]. It is believed that the stability of passive film and 
their repassivation kinetics are dependent on the metallurgy, applied passivation potentials, $\mathrm{pH}$ and chloride ion concentration in the aqueous solution [1] [5] [6]. Therefore, it is necessary to know the kinetics at which the passive film is formed on the stainless steels.

Reasons for the choice of UNS S32101 and UNS S30403 for this research are because these two alloys have been found to be competitors for applications in marine and oilfield environments [7]-[11]. Moreover, very few literatures exist on the repassivation kinetics of passive film in a $\mathrm{CO}_{2}$-saturated oilfield environment replicating service conditions where these two alloys find applications.

\section{Materials and Method}

Potentiostatic polarization tests were performed using EG \& G 263A model potentiostat/galvanostat and a three-electrode electrochemical set up consisting of an $\mathrm{Ag} / \mathrm{AgCl}$ reference electrode and a platinum counter electrode in order to obtain the current decay at constant applied potentials. The working electrode was polarized to a potential of $-850 \mathrm{mV}_{\mathrm{Ag} / \mathrm{AgCl}}$ for $1800 \mathrm{~s}$ to thin/remove the passive film formed in air [12]-[14]. The potential was then stepped to $-200,-100,0,100$, and $200 \mathrm{mV}_{\mathrm{Ag} / \mathrm{AgCl}}$. The chosen passive potential was then applied for 5 minutes and the potentiostatic current density was recorded. The data acquisition was 50 points/s in order to record higher number of points.

Meanwhile, in this study, oilfield brine (Table 1) was adopted. The oilfield brine was initially sparged with $\mathrm{CO}_{2}$ gas for $8 \mathrm{hrs}$ and stored in an air tight container. Before each experiment, the oilfield brine was sparged for one hour resulting in a $\mathrm{pH}$ of approximately 5.0 and the oxygen level less than $50 \mathrm{ppb}$. Moreover, $\mathrm{CO}_{2}$ was continuously fed into the solution throughout the duration of the experiment. Table 2 shows the composition of the alloys used for this research.

\section{Results and Discussion}

Figure 1 and Figure 2 show the anodic current transient for both alloys. It can be observed that for both alloys, the passive film repassivates at potentials of $0,-100$ and $-200 \mathrm{mV}$. This is shown by the steady decrease of current with time. The steady current decrease indicates anodic film growth [15]. A steady increase of current with time is however observed for both alloys at potentials of $100 \mathrm{mV}$ and $200 \mathrm{mV}$. A steady increase in current indicates corrosion as a result of anodic film dissolution. This indicates that the passive film is not protective at these potentials. Park et al. [16], also described such steady current increase to be as a result of metastable or stable corrosion pits.

\section{Table 1. Oilfield brine adopted for the research.}

\begin{tabular}{cc} 
Salts & $\mathrm{mg} / \mathrm{L}$ \\
$\mathrm{NaCl}$ (Sodium Chloride) & 24,090 \\
$\mathrm{KCl}$ (Potassium Chloride) & 706 \\
$\mathrm{CaCl}_{2} \cdot 2 \mathrm{H}_{2} \mathrm{O}$ (Calcium Chloride Di-hydrate) & 1387 \\
$\mathrm{MgCl}_{2}$ (Magnesium Chloride) & 4360 \\
$\mathrm{BaCl}_{2} \cdot 2 \mathrm{H}_{2} \mathrm{O}$ (Barium Chloride Di-hydrate) & 16 \\
$\mathrm{SrCl}_{2} \cdot 6 \mathrm{H}_{2} \mathrm{O}\left(\mathrm{Strontium} \mathrm{Chloride} \mathrm{Hexa-hydrate)} \mathrm{Na}_{2} \mathrm{SO}_{4}\right.$ (Sodium Sulphate) & 33 \\
$\mathrm{NaHCO}_{3}$ (Sodium Bicarbonate) & 3522 \\
\hline
\end{tabular}

Table 2. Composition of the alloys in solution annealed condition.

\begin{tabular}{ccccccccccc}
\hline Grade & Type & Cr & Ni & Mo & Cu & Mn & N & Fe & PREN \\
\hline UNS S30403 & Austenitic & 18.2 & 8.15 & 0.39 & 0.33 & 1.61 & 0.07 & Bal. & 20.6 \\
UNS S32101 & Lean duplex & 21.26 & 1.60 & 0.24 & 0.26 & 4.81 & 0.23 & Bal. & 25.7 \\
\hline
\end{tabular}




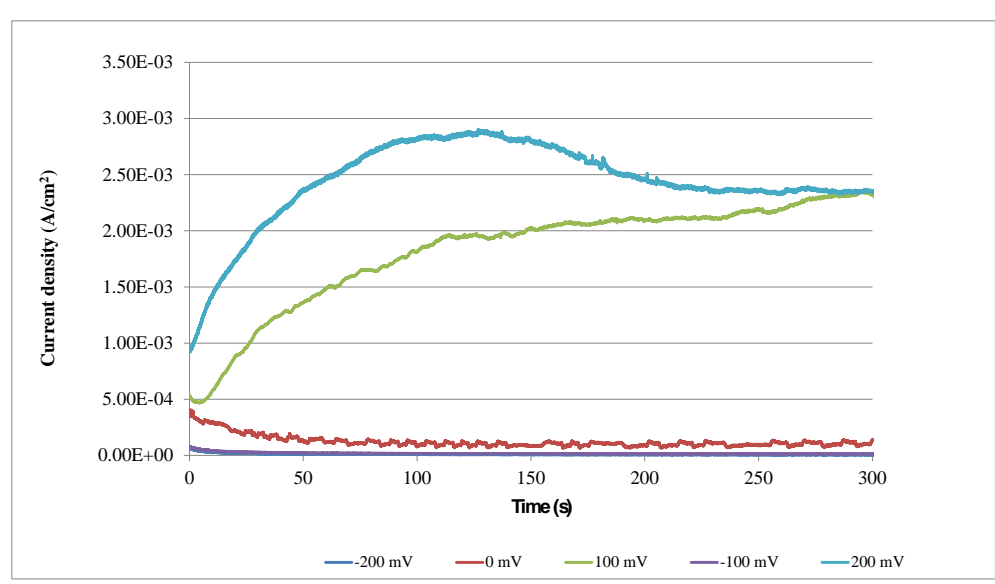

Figure 1. Anodic current transient for UNS S32101 after cathodic stripping at $50^{\circ} \mathrm{C}$.

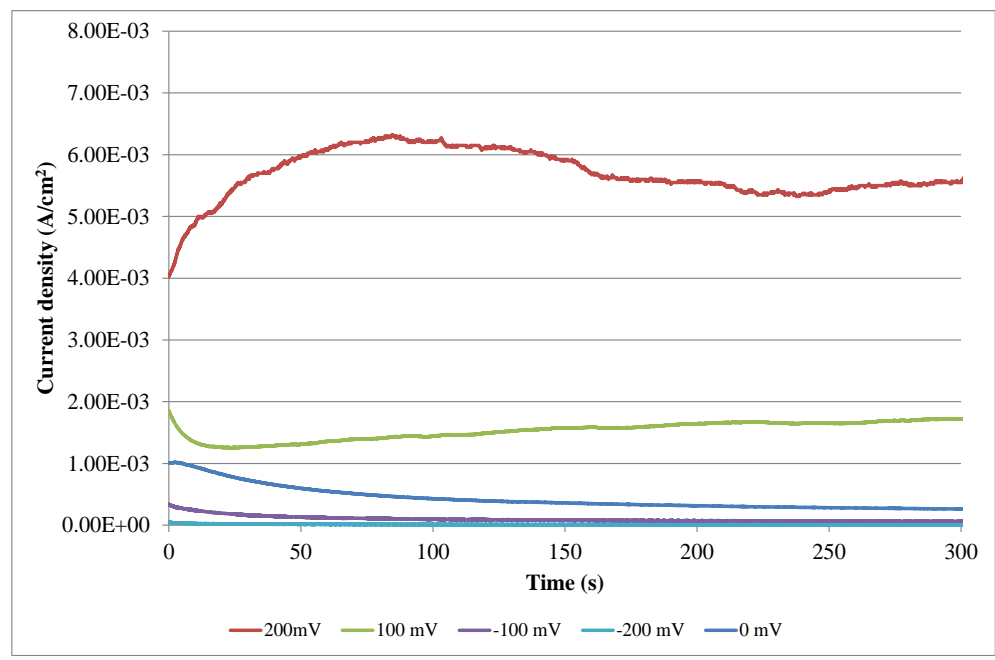

Figure 2. Anodic current transient for UNS S30403 after cathodic stripping at $50^{\circ} \mathrm{C}$.

During the current decrease (repassivation stage at lower potentials), three stages can be described. The stage of adsorption of metal-hydroxide species on the bare metal surface exposed to the medium, the stage of transformation of the adsorb layer to passive film and the stage of growth of passive film [17].

At higher potential, local anodic dissolution are promoted with the formation of pit nuclei [17]. However, at lower applied potential range that falls within the Tafel region, adsorbed metal-hydroxide species on bare surfaces of metals seems to be sufficiently stable to hinder metal dissolution [18]. This can be related to the behavior of the alloys at potentials of $-200 \mathrm{mV},-100 \mathrm{mV}$ and $0 \mathrm{mV}$ as shown in Figure 1 and Figure 2. As the applied anodic potential increased from the Tafel region to the active region, the rate of the dissolution of the passive film into solution increased. Hence the behavior of the alloys at potentials of 100 and $200 \mathrm{mV}$ as showed in Figure 1 and Figure 2.

Figure 3 and Figure 4 show the anodic current transients in logarithm scale for UNS S32101 and UNS $\mathrm{S} 30403$ in a $\mathrm{CO}_{2}$-saturated oilfield brine at $50^{\circ} \mathrm{C}$. Both figures show three stages [16] [19] corresponding to constant current stage, transition stage and a stage where the current either decreases or increases with time. The first stage (constant current) seems to be similar for both alloys at all potentials. Stage two also looks similar showing the start of current decay at potentials of $-200 \mathrm{mV},-100 \mathrm{mV}$ and $0 \mathrm{mV}$ and the start of increasing current at potentials of $100 \mathrm{mV}$ and $200 \mathrm{mV}$. The third stage also shows similarity for both alloys with a steep increase or decrease in current. There is a general decrease in current with time in logarithm scale for both alloys 


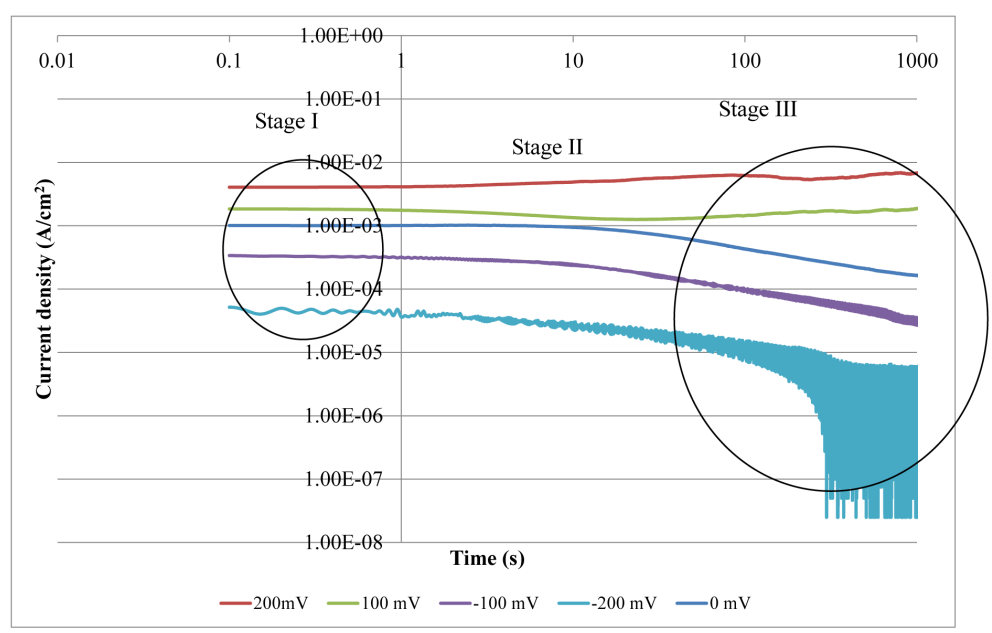

Figure 3. Anodic current transients in logarithm scale for UNS S30403 after cathodic stripping at $50^{\circ} \mathrm{C}$.

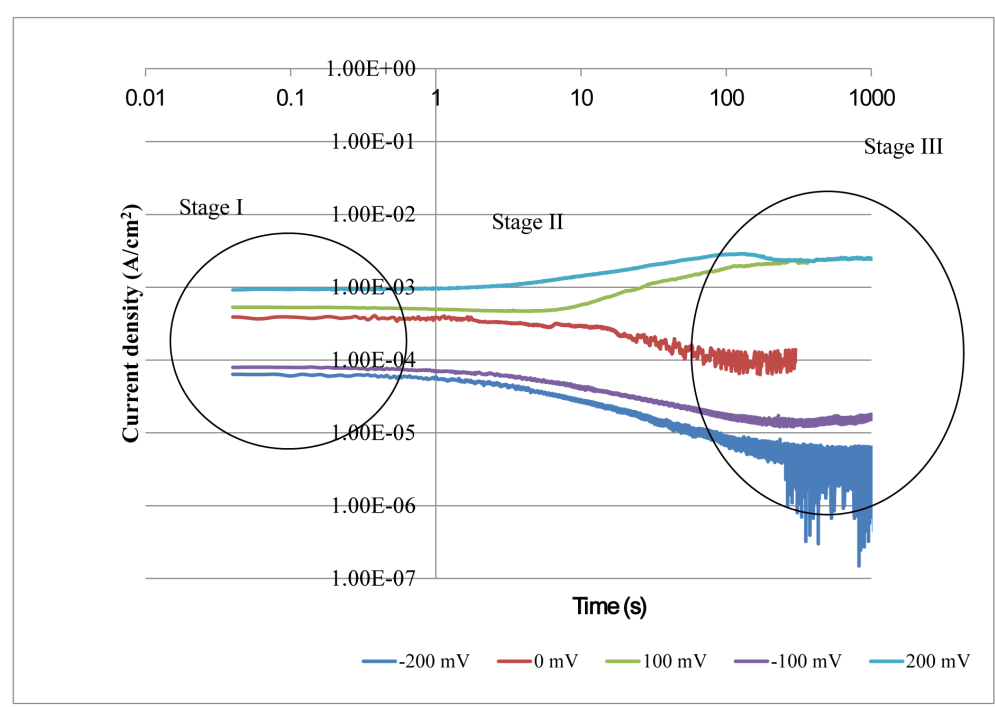

Figure 4. Anodic current transients in logarithm scale for UNS S32101 after cathodic stripping at $50^{\circ} \mathrm{C}$.

at potentials of $-200 \mathrm{mV},-100 \mathrm{mV}$ and $\mathrm{V} 0 \mathrm{mV}$. The current, however increases with time for potentials of 100 $\mathrm{mV}$ and $200 \mathrm{mV}$ at stage III.

The current density recorded corresponds to the total current density resulting from the film formation and dissolution of the alloys in the solution [5]. The three stages (Figure 3 and Figure 4) described above can be explained thus: Stage $\mathbf{I}$ is the constant current stage where the rate of oxide formation and dissolution is equal [16] [19]. At this stage oxide film hardly grows. Stage II corresponds to the transition zone where the current density either starts to decrease or increase, depending on whether the passive film is protective or non-protective. Stage III is the region where the anodic current density either decreases or increases linearly in logarithm scale depending on whether the passive film is passivating or dissolving/depassivating. If the current decreases it means that the passive film is repassivating and hence it is protective. The converse is the case when the current increases.

It can also be observed that at potentials of $-200 \mathrm{mV},-100 \mathrm{mV}$ and $0 \mathrm{mV}$, the rate of passivation dominates the rate of dissolution. This implies that the alloy may not be susceptible to pitting corrosion at these potentials. However, at potentials of $100 \mathrm{mV}$ and above, the rate of dissolution is higher than the rate of passivation as indicated by a steady rise in the current density in logarithm scale in Figure 3 and Figure 4. This implies that the 
passive film may not be protective at potentials above this value.

\section{Conclusions}

1) The passive film formed on both UNS S32101 and UNS S30403 after an initial cathodic stripping repassivates at potentials of $-200 \mathrm{mV},-100 \mathrm{mV}$ and $0 \mathrm{mV}$ at $50^{\circ} \mathrm{C}$. This is shown by the continuous steady anodic current decrease for both alloys at these test potentials.

2) The passive film formed on both UNS S32101 and UNS S30403 does not repassivate at potentials of 100 $\mathrm{mV}$ and $200 \mathrm{mV}$ the test temperature of $50^{\circ} \mathrm{C}$. This is shown by the continuous steady anodic current increase for both alloys at these test potentials, both alloys are therefore susceptible to pitting corrosion at these potentials.

3) UNS S32101 and UNS S30403 behaved similarly in the oilfield brine used for this research. Both alloys are therefore likely to have similar resistance to localized corrosion and stress corrosion cracking. This is because both pitting corrosion and stress corrosion cracking depend on the repassivation behavior of passive film.

\section{References}

[1] Lee, J.-B. (2006) Effects of Alloying Elements, Cr, Mo and N on Repassivation Characteristics of Stainless Steels Using the Abrading Electrode Technique. Materials Chemistry and Physics, 99, 224-234. http://dx.doi.org/10.1016/j.matchemphys.2005.10.016

[2] Jegdic, B., Drazic, D.M. and Popic, J.P. (2008) Open Circuit Potentials of Metallic Chromium and Austenitic 304 Stainless Steel in Aqueous Sulphuric Acid Solution and the Influence Chloride Ions on Them. Corrosion Science, 50, 1235-1244. http://dx.doi.org/10.1016/j.corsci.2008.01.012

[3] Ibrahim, A.M.M., Abd El Rehim, S.S. and Hamza, M.M. (2009) Corrosion Behavior of Some Austenitic Stainless Steels in Chloride Environments. Material Chemistry and Physics, 115, 80-85. http://dx.doi.org/10.1016/j.matchemphys.2008.11.016

[4] De Christofaro, N., Piantini, M. and Zacchetti, N. (1997) The Influence of Temperature on the Passivation Behavior of a Super Duplex Stainless Steel in a Boric-Borate Buffer Solution. Corrosion Science, 39, 2181-2191. http://dx.doi.org/10.1016/S0010-938X(97)00101-7

[5] El Hajjaji, S., Aries, L., Pebere, N., Dabosi, F., Audouar, J.P. and Benbachir, A. (1996) Passive State Behavior of special Austenitic and Ferritic Stainless Steels in Phosphoric Acid Polluted by Sulfide Ions. Corrosion Science, 52, 865871. http://dx.doi.org/10.5006/1.3292079

[6] Newman, R.C. (1985) The Dissolution and Passivation Kinetics of Stainless Alloy Containing Molybdenum. Coulometric Studies of Fe-Cr and Fe-Cr-Mo Alloys. Corrosion Science, 25, 331-339.

http://dx.doi.org/10.1016/0010-938X(85)90111-8

[7] Gudme, J. and Nielsen, T.S. (2009) Qualification of Lean Duplex Grade LDX 2101 (UNS S32101) for Carcass Material in Flexible Pipes. Proceedings of the NACE Corrosion Conference, Atlanta, 22-26 March 2009, Paper No. 09075.

[8] Wei, Z., Laizhu, J., Jincheng, H. and Hongmei, S. (2008) Study of Mechanical and Corrosion Properties of a Fe21.4Cr-6Mn-1.5Ni-0.24N-0.6Mo Duplex Stainless Steel. Materials Science and Engineering: A, 497, 501-504. http://dx.doi.org/10.1016/j.msea.2008.07.062

[9] Merello, R., Botana, F.J., Botella, J., Matres, M.V. and Marcos, M. (2003) Influence of Chemical Composition on the Pitting Corrosion Resistance of Non-Standard Low-Ni High-Mn-N Duplex Stainless Steels. Corrosion Science, 45, 909-921. http://dx.doi.org/10.1016/S0010-938X(02)00154-3

[10] Johansson, E. and Prosek, T. (2007) Stress Corrosion Cracking Properties of UNS S32101-A New Duplex Stainless Steel with Low Nickel Content. Proceedings of the NACE Corrosion Conference, Nashville, 11-15 March 2007, Paper No. 07475.

[11] Iversen, A., Qvarfort R. and Bergqvist, A. (2005) Corrosion Properties of S32101-A New Duplex Stainless Steel, with Low Nickel Content for Use as Reinforcement in Concrete. Proceedings of the NACE Corrosion Conference, Houston, 3-7 April 2005, Paper No. 05260.

[12] Li, N., Li, Y., Wang, S. and Wang, F. (2006) Electrochemical Corrosion Behavior of Nano Crystallized Bulk 304 Stainless Steel. Electrochimica Acta, 52, 760-765. http://dx.doi.org/10.1016/j.electacta.2006.06.023

[13] Qiao, Y.X., Zheng, Y.G., Okafor, P.C. and Ke, W. (2009) Electrochemical Behavior of High Nitrogen Bearing Stainless Steel in Acidic Chloride Solution: Effects of Oxygen, Acid Concentration and Surface Roughness. Electrochimica Acta, 54, 2298-2304. http://dx.doi.org/10.1016/j.electacta.2008.10.038 
[14] Qiao, Y.X., Zheng, Y.G., Ke, W. and Okafor, P.C. (2009) Electrochemical Behavior of High Nitrogen Stainless Steel in Acidic Solutions. Corrosion Science, 51, 979-986. http://dx.doi.org/10.1016/j.corsci.2009.02.026

[15] Jemmely, P. Mischler, S. and Landolt, D. (2000) Electrochemical Modeling of Passivation Phenomena in Tribocorrosion. Wear, 237, 63-76. http://dx.doi.org/10.1016/S0043-1648(99)00314-2

[16] Park, J.-J., Pyun, S.-I., Lee, W.-J. and Kim, H.-P. (1999) Effect of Bicarbonate Ion Additives on Pitting Corrosion of Type 316L Stainless Steel in Aqueous 0.5 M Sodium Chloride Solution. Corrosion, 55, 380-387.

[17] Ahila, S., Reynders, B. and Grabk, H.J. (1996) The Evaluation of the Repassivation Tendency of Cr-Mn and Cr-Ni Steels Using Scratch Technique. Corrosion Science, 38, 1991-2005.

[18] Kim J.-D. and Pyun S.-I. (1996) The Effects of Applied Potential and Chloride ion on the Repassivation Kinetics of Pure Iron. Corrosion Science, 38, 1093-1102.

[19] Escrivà-Cerdán, C., Blasco-Tamari, E., García-García, D., García-Antón, J. and Guenbour, A. (2012) Passivation Behaviour of Alloy 31 (UNS N08031) in Polluted Phosphoric Acid at Different Temperatures. Corrosion Science, 56, 114-112. http://dx.doi.org/10.1016/j.corsci.2011.11.014 